\title{
APLIKASI PENJUALAN PAKAIAN COUPLE BERBASIS WEBSITE PADA RAIN-D SHOP SAMARINDA
}

\author{
M. Irwan Ukkas ${ }^{1)}$, Kusno Harianto ${ }^{2)}$, Muh. Husain Nooor Hidayat ${ }^{\text {3) }}$ \\ ${ }^{1,2}$ Sistem Informasi, STMIK Widya Cipta Dharma \\ ${ }^{3}$ Teknik Informatika,STMIK Widya Cipta Dharma \\ $1,2,3$ Jl. Prof. M. Yamin No. 25, Samarinda, 75123 \\ E-mail : Irwan212@yahoo.com ${ }^{1)}$, kusnoharianto97.kh@ gmail.com ${ }^{2)}$, hidayatstmik@ gmail.com ${ }^{3)}$,
}

\begin{abstract}
ABSTRAK
Penelitian ini dilakukan bertujuan untuk membuat Aplikasi Penjualan Pakaian Couple Berbasis Website pada Rain-D Shop Samarinda yang memudahkan pelanggan dalam pembelian produk yang diinginkan. Alat bantu pengembangan sistem yang digunakan yaitu flowchart dengan menggunakan bahasa pemrograman PHP serta database MySQL.

Maka dihasilkan sebuah informasi Penjualan Online Pada Rain-D Shop Samarinda yang dapat memberi kemudahan pada masyarakat untuk mendapatkan informasi tentang penjualan dan informasi produk-produk terbaru yang ditawarkan oleh Rain-D Shop Samarinda. Sistem penjualan ini juga dapat membantu kinerja admin yaitu dengan mudah menambah, mengganti \& menghapus data.
\end{abstract}

Kata Kunci: Aplikasi, Penjualan, Pakaian Couple, Website,

\section{PENDAHULUAN}

Di zaman sekarang teknologi informasi dalam bidang Web semakin maju dan berkembang dengan pesatnya di negara-negara maju seperti Indonesia. Diharapkan semua komponen masyarakat baik itu instansi pemerintah, bisnis, sekolah-sekolah, serta organisasi saling berlomba untuk memberikan sajian informasi yang terbaik, cepat dan tepat dalam bidang Web. Pada Toko Rain-D Shop dalam jangkauan memberikan informasi kepada masyarakat masih bersifat umum. Jadi pada Toko perlu dikembangkan proses informasi dan transaksi penjualan pakaian dengan menggunakan Web site, sehingga informasi yang diberikan dapat lebih dikenal oleh lingkungan luar maupun lingkungan dalam toko terutama setiap pelanggan yang akan melakukan pencarian pakaian yang di inginkan. Dengan adanya sistem informasi ini diharapkan akan lebih efektif dan efisien serta akurat dalam mencapai suatu sasaran.

\section{RUANG LINGKUP PENELITIAN}

Permasalahan difokuskan pada:

1. Pembelian secara online.

2. Sistem memberikan informasi-informasi yang terdapat pada halaman home dan halaman berita tentang seputar Rain-D shop dan berita yang berkaitan dengan baju Couple (pasangan) antara lain diskon dan berita lainnya.

3. Sistem dapat melakukan pengumpulan barang yang ingin dibeli dalam keranjang belanja.
4. Sistem mampu memberikan laporan serta mencetak laporan tiap minggu, bulan dan tahun sesuai kategori yang dipilih dalam bentuk PDF maupun langsung diprint.

5. Sistem mampu menampilkan keranjang belanja dengan field nama produk, jumlah produk, harga dan total harga seluruh barang yang akan dibeli.

\section{BAHAN DAN METODE}

Penulis membuat menggunakan macromedia dreamwaver sebagai editor dan mySQL sebagai database.Metode yang digunakan ialah menggunakan waterfall.

\subsection{Macromedia Dreamwaver}

Menurut Madcom (2008) Dreamweaver adalah salah satu editor Web yang banyak digunakan oleh para programmer. Software ini semula dibangun oleh Macromedia, tetapi belakangan diakusisi oleh Adobe. Mengunakan Dreamweaver tidak sesulit menulis kode program. Tampilan Dreamweaver sangat user friendly, sehingga memudahkan untuk mempelajarinya meski bagi pemula.

\subsection{Metode Air Terjun}

Model air terjun (waterfall) adalah model satu arah yang dimulai dari tahap persiapan sampai perawatan, dan model inilah yang dipakai oleh penulis dalam menganalisa sistem yang akan dikerjakan (Pressman, 2002). Adapun tahapan yang terdapat dalam waterfall model dapat dijelaskan seperti di bawah ini: 
1. Requirements analysis and definition : mengumpulkan kebutuhan secara lengkap kemudian dianalisis dan didefinisikan kebutuhan yang harus dipenuhi oleh program yang akan dibangun. Fase ini harus dikerjakan secara lengkap untuk bias menghasilkan desain yang lengkap.

2. Sistem and Software design: desain dikerjakan setelah kebutuhan selesai dikumpulkan seecara lengkap.

3.Implementation and unit testing : desain program diterjemahkan ke dalam kode-kode dengan menggunakan bahasa pemrograman yang sudah ditentukan. Program yang dibangun langsung diuji baik secara unit.

4.Integration and sistem testing: penyatuan unit-unit program kemudian diuji secara keseluruhan (sistem testing).

5. Operation and maintenance: mengoperasikan program dilingkungannya dan melakukan pemeliharaan, seperti penyesuaian atau perubahan karena adaptasi dengan situasi yang sebenarnya.

\section{RANCANGAN APLIKASI}

Perancangan Aplikasi ini menggunakan flowchart,yaitu flowchart admin dan member,dapat dilihat pada gambar sebagai berikut :

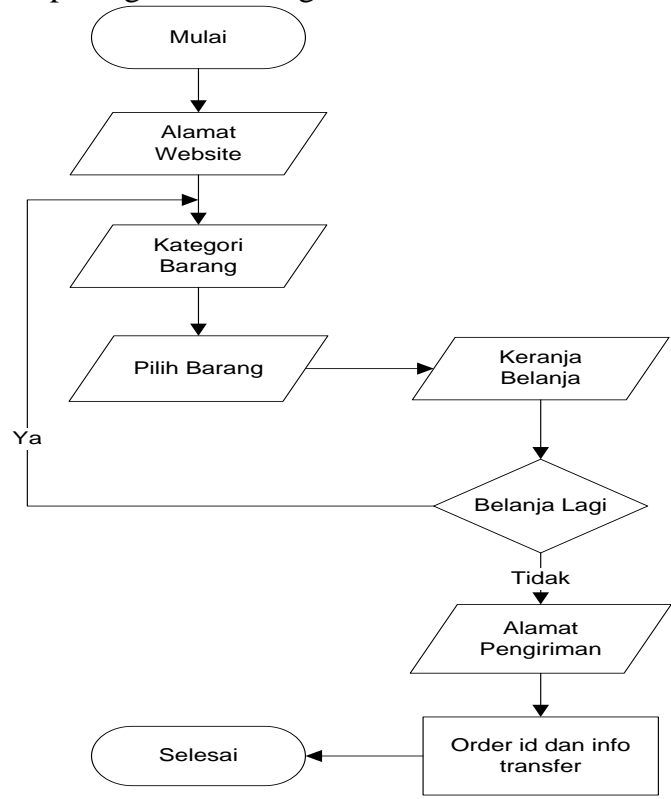

Gambar 1. Gambaran Flowchart Member

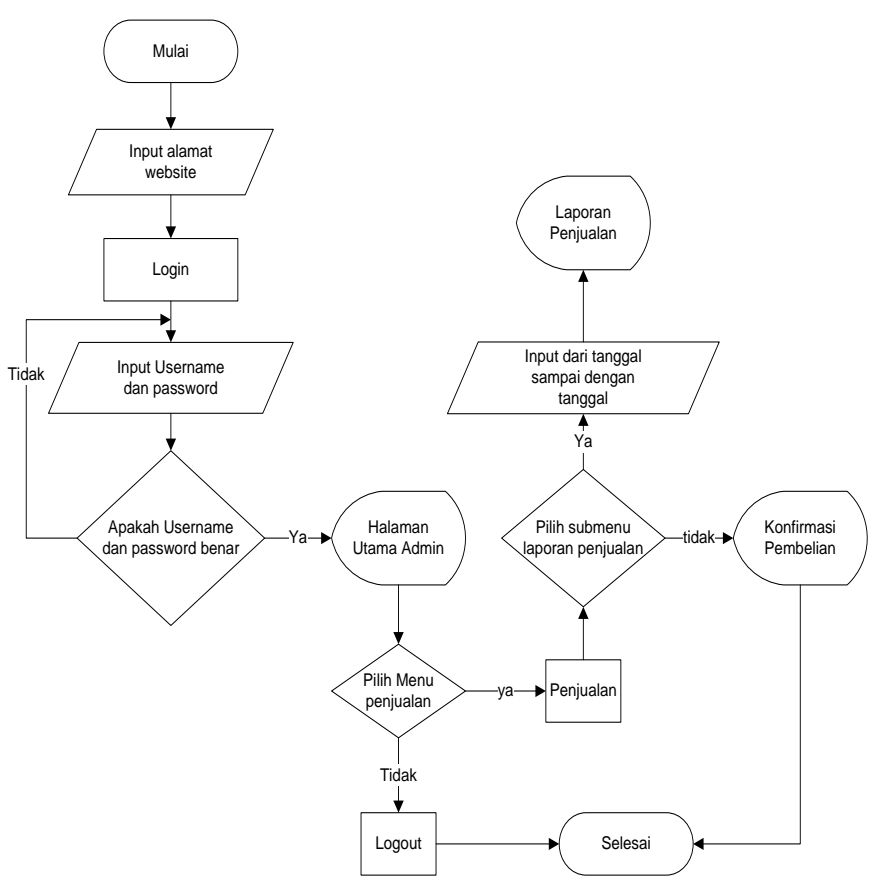

Gambar 2. Gambaran Flowchart Admin

\subsection{Kebutuhan Fungsional}

Jenis kebutuhan fungsional adalah kebutuhan yang berisi proses-proses apa saja yang nantinya dilakukan oleh sistem. Kebutuhan fungsional juga berisi informasiinformasi apa saja yang harus ada dan dihasilkan sistem. Didalamnya terdapat beberapa komponen antara lain :

\begin{tabular}{|c|c|c|}
\hline No & User & Deskripsi \\
\hline \multirow[t]{3}{*}{1.} & \multirow[t]{3}{*}{ Admin } & $\begin{array}{l}\text { Untuk mengakses halaman utama } \\
\text { control panel maka admin harus } \\
\text { melakukan login terlebih dahulu } \\
\text { untuk memastikan bahwa User yang } \\
\text { mengakses halaman ini telah } \\
\text { terdaftar }\end{array}$ \\
\hline & & $\begin{array}{l}\text { Sistem harus bisa menampilkan } \\
\text { data, entri data baru, mengupdate, } \\
\text { dan menghapus informasi pada tabel } \\
\text { produk melalui menu yang telah } \\
\text { disediakan. }\end{array}$ \\
\hline & & $\begin{array}{l}\text { Sistem harus bisa menampilkan } \\
\text { data, entri data baru, mengupdate, } \\
\text { dan menghapus informasi pada } \\
\text { proses pemesanan, konfirmasi } \\
\text { bayar, pengiriman, melalui menu } \\
\text { yang telah disediakan. }\end{array}$ \\
\hline \multirow[t]{2}{*}{2} & \multirow[t]{2}{*}{ Member } & $\begin{array}{l}\text { Sistem harus bisa menampilkan } \\
\text { daftar permohonan transaksi sesuai } \\
\text { User yang login . }\end{array}$ \\
\hline & & $\begin{array}{l}\text { Sistem harus bisa menampilkan } \\
\text { informasi dan konfirmasi status } \\
\text { produk yang di pesan oleh User } \\
\text { yang login. }\end{array}$ \\
\hline
\end{tabular}

Tabel 1. Kebutuhan Fungsional (Functional Requirement) 


\section{IMPLEMENTASI}

Berikut hasil implementasi dari metode waterfall,dimana impelementasi ini bertahap dan tidak akan melanjutkan ketahap selanjutnya jika tahap tersebut belum terselesaikan :

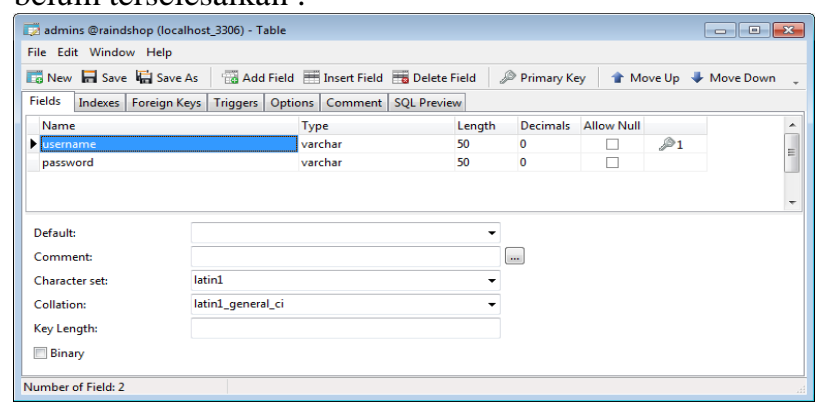

\section{Tabel 2.Tabel Admins}

Keterangan : merupakan tabel untuk menyimpan username dan password.

Primary key : username.

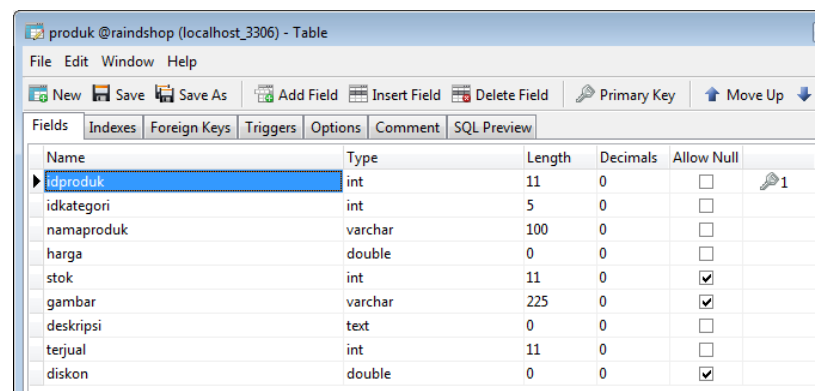

Tabel 3.Tabel Produk

Keterangan : merupakan tabel untuk menyimpan produk. Primary key : idproduk.

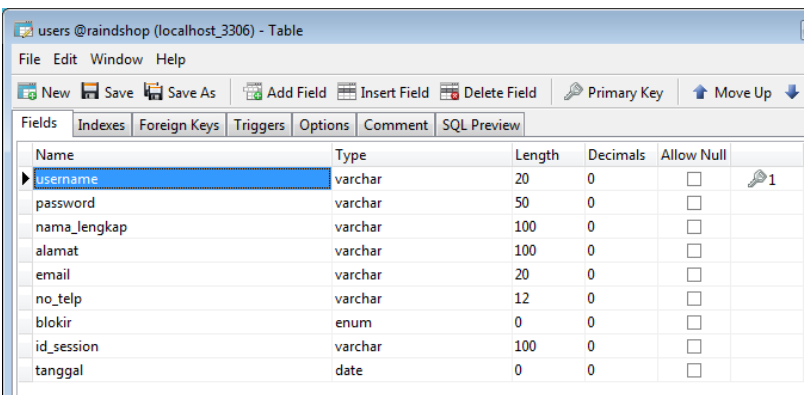

Tabel 4.Tabel Member

Keterangan : merupakan tabel untuk menyimpan data member atauu pelanggan.

Primary key : username

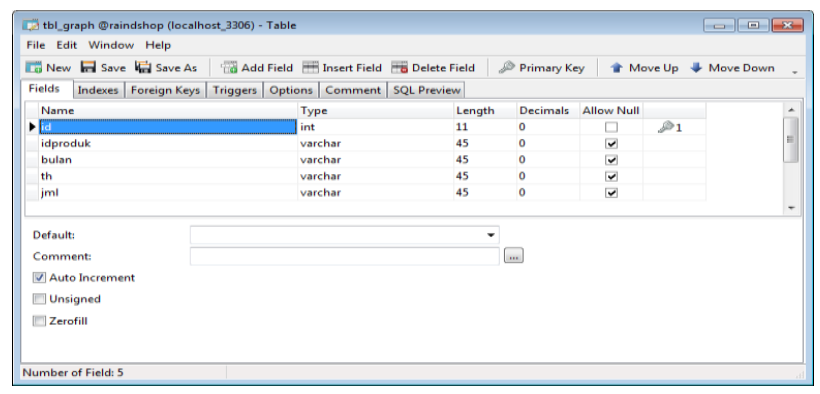

Tabel 5.Tabel Grafik
Keterangan : merupakan tabel untuk menyimpan data penjualan yang nantinya akan dihasilkan dalam bentuk grafik.

Primary key : id

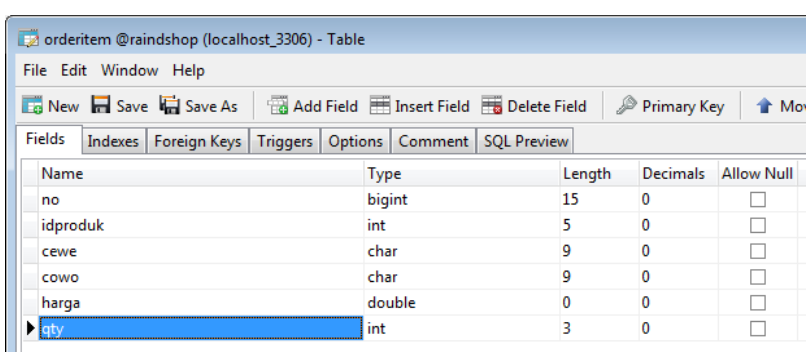

Tabel 6.Tabel Pemesanan

Keterangan : merupakan tabel untuk menyimpan data barang yang telah dipesan oleh pelanggan

Primary key : -

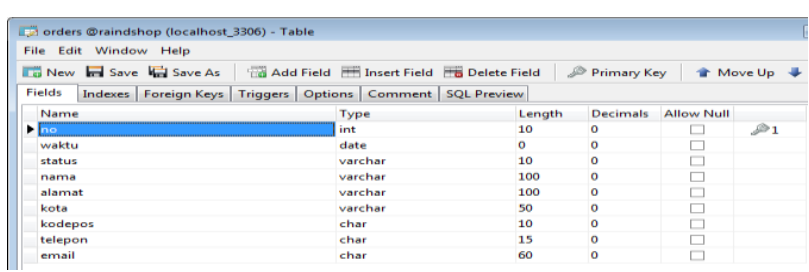

Tabel 7.Tabel Orders

Keterangan : merupakan tabel untuk menyimpan data pelanggan yang melakukan transaksi.

Primary key : -

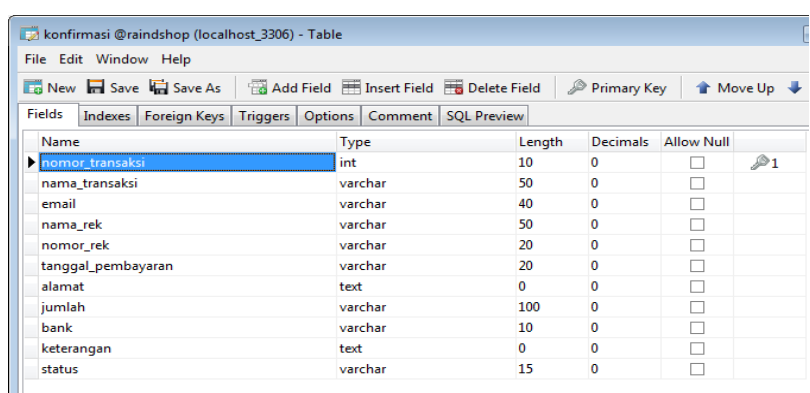

Tabel 8.Tabel Konfirmasi

Keterangan : merupakan tabel untuk menyimpan data pelanggan yang melakukan konfirmasi pemesanan.

Primary key : nomor_Transaksi.

\begin{tabular}{|c|c|c|c|c|}
\hline \multicolumn{4}{|c|}{ 1E. kota @raindshop (localhost_3306) - Table } & $\square 0$ \\
\hline \multicolumn{5}{|l|}{ File Edit Window Help } \\
\hline 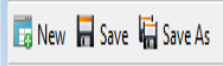 & \multicolumn{2}{|c|}{ 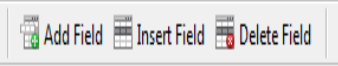 } & \multirow[t]{2}{*}{ P Primary Key } & \multirow[t]{2}{*}{ Move Up } \\
\hline \begin{tabular}{l|l|l} 
Fields Inderes & Foreign Keys
\end{tabular} & \begin{tabular}{|l|l|} 
Triggers & Options \\
\end{tabular} & \begin{tabular}{|l|l|} 
Comment & SQL Preview \\
\end{tabular} & & \\
\hline Name & Typ & Length & h Decimals A & Allow Null \\
\hline$\sqrt{\text { d kota }}$ & var & char & 0 & P1 \\
\hline ongkos_kirim & int & 10 & 0 & $\square$ \\
\hline
\end{tabular}

Tabel 9.Tabel Kota

Keterangan : merupakan tabel untuk menyimpan data kota beserta ongkos kirimnya yang digunakan untuk transaksi pada website tersebut.

Primary key : id_kota

5.1 Tampilan Pada Halaman Website Untuk Admin 
Berikut tampilan website untuk halaman admin Rain-D Shop :

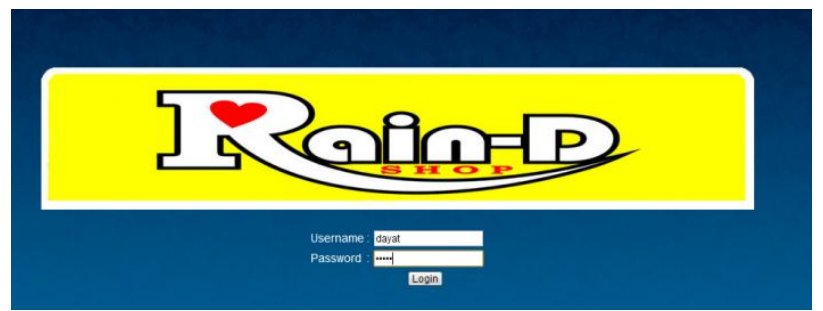

Gambar 3. Halaman Pada Admin Rain-D Shop

Pada halaman ini berisikan username dan password pada halaman rain-D shop.

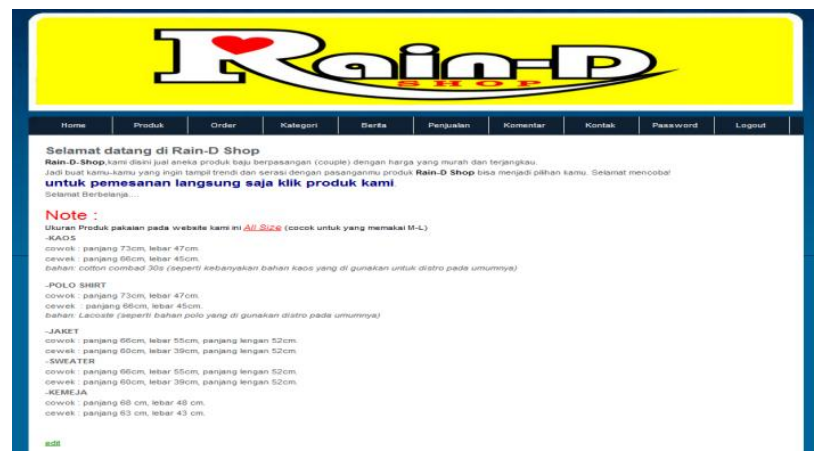

Gambar 4. Halaman Utama Pada Admin Rain-D Shop

Pada halaman ini merupakan halaman utama pada admin,dimana ada sub menu dari home sampai melakukan tahap akhir yaitu checkout atau logout.

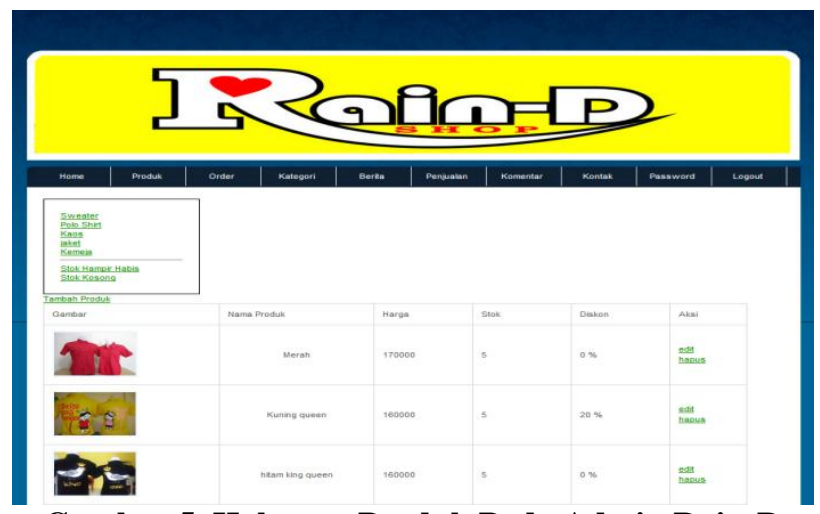

Gambar 5. Halaman Produk Pada Admin Rain-D Shop

Pada Halaman ini sang administrator dapat melihat produk dan dapat mengupdate produk-produk yang ada pada rain-D shop,dapat pula menentukan seberapa besarnya diskon yang terdapat pada rain-D shop.

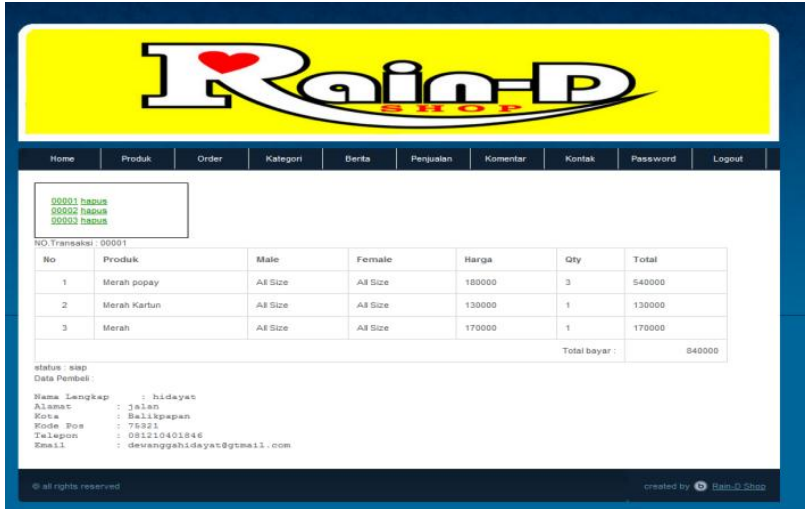

Gambar 6. Halaman Order Pada Admin Rain-D Shop

merupakan halaman dari admin yang digunakan untuk melihat pesanan detail dari member

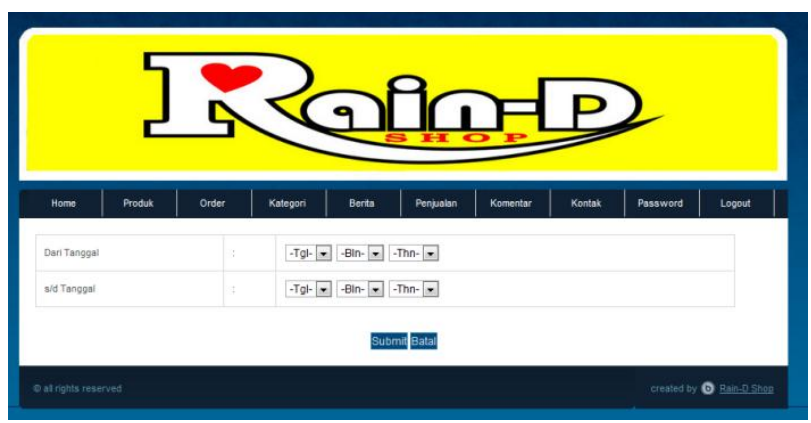

Gambar 7. Halaman Laporan penjualan Pada Admin Rain-D Shop

merupakan halaman untuk melihat penjualan berdasarkan periode dari tanggal sampai dengan tanggal berapa yang diinginkan oleh admin. Kemudian admin klik submit.

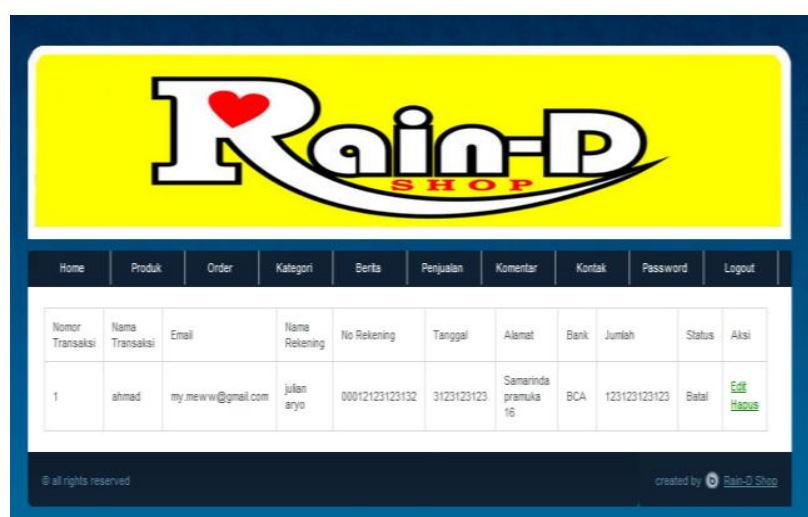

Gambar 8. Halaman Konfirmasi pembelian Pada Admin Rain-D Shop

Merupakan halaman pada member untuk melihat siapa pelanggan yang telah melakukan konfirmasi pemesanan. 


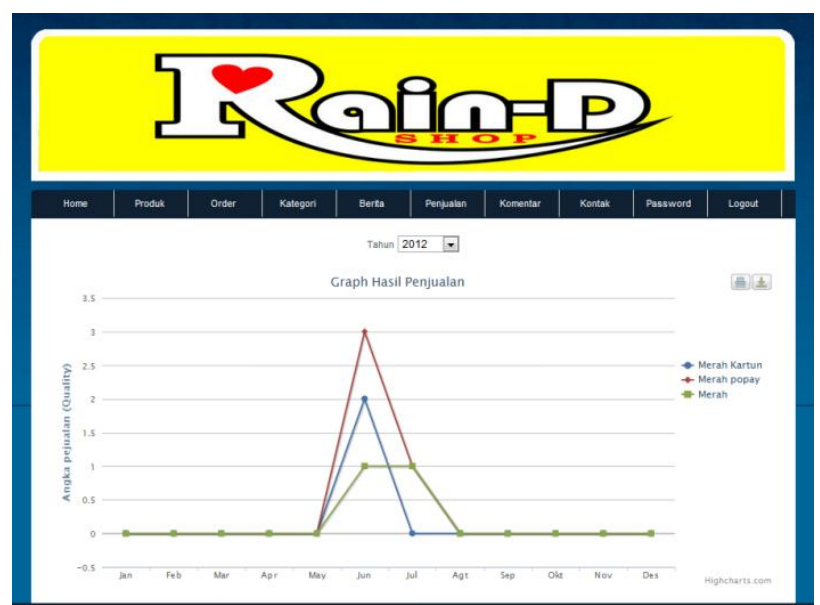

Gambar 9. Halaman Grafik pembelian Pada Admin Rain-D Shop

Merupakan halaman untuk melihat tampilan grafik penjualan pad arain-d shop dalam laporan bulanan dan melihat berdasarkan produk apa saja yang telah terjual.

\subsection{Pengujian Black box}

Metode black box adalah cara pengujian hanya dilakukan dengan menjalankan atau mengeksekusi unit atau modul, kemudian diamati apakah hasil dari unit itu sesuai dengan proses bisnis yang diinginkan. Pengujian terhadap Pengembangan aplikasi Web site penjualan pakaian couple pada Rain-D Shop Samarinda dilakukan terhadap uji masukan data, uji transaksi dan uji integritas yang dilakukan dengan cara membandingkan antara hasil yang dilakukan secara manual dan dilakukan dengan sistem,berikut hasilnya :

\begin{tabular}{|c|c|c|}
\hline Penguji & Modul & Hasil \\
\hline $\begin{array}{c}\text { Julian Aryo, Ahmad } \\
\text { Muhrani, Randy } \\
\text { Herman }\end{array}$ & Form login & Berhasil \\
\hline $\begin{array}{c}\text { Julian Aryo, Ahmad } \\
\text { Muhrani, } \text { Randy } \\
\text { Herman }\end{array}$ & $\begin{array}{c}\text { Form Order, } \\
\text { Form } \\
\text { Konfirmasi } \\
\text { Pembayaran }\end{array}$ & Berhasil \\
\hline $\begin{array}{c}\text { Normansyah, Ady } \\
\text { Suyoko }\end{array}$ & $\begin{array}{c}\text { Formsaksi pada } \\
\text { admin }\end{array}$ & Berhasil \\
\hline
\end{tabular}

Tabel 10. Pengujian Black Box

\subsection{Pegujian Beta}

Pengujian beta merupakan pengujian yang dilakukan secara objektif yang di uji secara langsung oleh pengisi kuesioner yang diisi oleh 3 orang responden member dan 2 orang responden admin.

\section{Pengujian halaman Member}

1. Pengujian fasilitas Website untuk mengupload informasi tentang rain-d shop di website dapat dilihat pada tabel berikut :

\begin{tabular}{|l|l|l|l|}
\hline No & Keterangan & $\begin{array}{l}\text { Banyak } \\
\text { Jawaban }\end{array}$ & $\begin{array}{l}\text { Presentase } \\
(\%)\end{array}$ \\
\hline 1 & $\begin{array}{l}\text { Sangat } \\
\text { Memenuhi }\end{array}$ & 0 & 0 \\
\hline 2 & $\begin{array}{l}\text { Cukup } \\
\text { Memenuhi }\end{array}$ & 2 & 66,67 \\
\hline 3 & Memenuhi & 1 & 33,33 \\
\hline 4 & $\begin{array}{l}\text { Kurang } \\
\text { Memenuhi }\end{array}$ & 0 & 0 \\
\hline 5 & Tidak Memenuhi & 0 & 0 \\
\hline \multicolumn{2}{|l|}{ Total Responden } & 3 & \\
\hline
\end{tabular}

Tabel 11. Hasil pengujian fasilitas pada halaman admin

Berdasarkan hasil presentase pada tabel 4. 21 maka dapat di simpulkan bahwa sebanyak 2 dari 3 orang responden atau 66,67 \% mengatakan bahwa fasilitas untuk mengupload materi guru, input latihan soal, input ulangan, dan forum diskusi di website Cukup memenuhi keinginan dan sebanyak 1 dari 3 orang atau 33,33\% mengatakan memenuhi keinganan user.

2. Pengujian menu halaman admin yang ada pada website apakah sudah jelas untuk mewakili halaman yang terkait dapat dilihat pada tabel 4. 22

\begin{tabular}{|l|l|l|l|}
\hline No & Keterangan & $\begin{array}{l}\text { Banyak } \\
\text { Jawaban }\end{array}$ & $\begin{array}{l}\text { Presentase } \\
(\%)\end{array}$ \\
\hline 1 & Sangat Jelas & 2 & $66,67 \%$ \\
\hline 2 & Cukup Jelas & 1 & $33,33 \%$ \\
\hline 3 & Jelas & 0 & $0 \%$ \\
\hline 4 & Kurang Jelas & 0 & $0 \%$ \\
\hline 5 & Tidak Jelas & 0 & $0 \%$ \\
\hline Jumlah & 3 & \\
\hline
\end{tabular}

Tabel 12. Hasil pengujian menu halaman admin

Berdasarkan hasil presentase pada tabel 4.22 maka dapat di simpulkan bahwa sebanyak 2 dari 3 orang responden atau 66,67 \% mengatakan menu pada halaman admin sudah sangat jelas untuk mewakili halaman terkait dan sebanyak 1 dari 3 orang responden atau 33,33\% mengatakan cukup jelas

3. Pegujian layout (susunan/letak) pada setiap fungsi (seperti fungsi menu, input, dan lainnya) dalam website apa sudah baik dapat dilihat pada tabel 4.23

\begin{tabular}{|l|l|l|l|}
\hline No & Keterangan & $\begin{array}{l}\text { Banyak } \\
\text { Jawaban }\end{array}$ & $\begin{array}{l}\text { Presentase } \\
(\%)\end{array}$ \\
\hline 1 & Sangat Baik & 0 & 0 \\
\hline 2 & Cukup Baik & 1 & 33,33 \\
\hline 3 & Baik & 2 & 66,67 \\
\hline 4 & Kurang Baik & 0 & 0 \\
\hline 5 & Tidak Baik & 0 & 0 \\
\hline \multicolumn{2}{|l}{ Total Responden } & 3 & \\
\hline
\end{tabular}

Tabel 13. Hasil pengujian Layout (tata letak) pada setiap fungsi

Berdasarkan hasil presentase pada tabel 4.23 maka dapat di simpulkan bahwa sebanyak 1 dari 3 orang responden atau 33,33 \% mengatakan layout pada halaman website cukup baik dan sebanyak 2 dari 3 orang responden atau $66,67 \%$ mengatakan layout pada halaman website baik 
4. Pengujian akses loading (kecepatan) website waktu memasuki halaman awal (index) dapat dilihat pada tabel 4.24.

\begin{tabular}{|l|l|l|l|}
\hline No & Keterangan & $\begin{array}{l}\text { Banyak } \\
\text { Jawaban }\end{array}$ & $\begin{array}{l}\text { Presentase } \\
(\%)\end{array}$ \\
\hline 1 & Sangat Cepat & 0 & 0 \\
\hline 2 & Cukup Cepat & 1 & 33,33 \\
\hline 3 & Cepat & 1 & 33,33 \\
\hline 4 & Kurang Cepat & 1 & 33,33 \\
\hline 5 & Sangat Lambat & 0 & 0 \\
\hline \multicolumn{2}{|l}{ Total Responden } & 3 & \\
\hline
\end{tabular}

Tabel 14. Hasil pengujian Akses loading (kecepatan)

Berdasarkan hasil presentase pada tabel 11 maka dapat di simpulkan bahwa sebanyak 1 dari 3 orang responden atau 33,33\% mengatakan kecepatan akses halaman awal user guru pada halaman website cukup cepat dan sebanyak 1 dari 3 orang responden atau 33,33\% mengatakan kecepatan akses halaman awal user siswa guru halaman website cepat serta sebanyak 1 dari 3 orang responden atau 33,33\% mengatakan kecepatan akses halaman awal user guru pada halaman website kurang cepat

5. Pengujian desain interface (tampilan halaman admin) pada website dapat dilihat pada tabel 4.25

\begin{tabular}{|l|l|l|l|}
\hline No & Keterangan & $\begin{array}{l}\text { Banyak } \\
\text { Jawaban }\end{array}$ & $\begin{array}{l}\text { Presentase } \\
(\%)\end{array}$ \\
\hline 1 & Sangat Menarik & 0 & 0 \\
\hline 2 & Cukup Menarik & 0 & 0 \\
\hline 3 & Menarik & 0 & 0 \\
\hline 4 & Kurang Menarik & 3 & 100 \\
\hline 5 & Tidak Menarik & 0 & 0 \\
\hline \multicolumn{2}{|l}{ Total Responden } & 3 & \\
\hline
\end{tabular}

Tabel 15. Hasil pengujian Desain Interface (tampilan halaman admin)

Berdasarkan hasil presentase pada tabel 4.25 maka dapat di simpulkan bahwa sebanyak 3 dari 3 orang responden atau $100 \%$ mengatakan Desain interface ( tampilan) halaman awal admin pada halaman website kurang menarik

6. Pengujian interaksi antara website dan pengguna ( user ) dapat dipahami dengan baik oleh sistem dan user dapat dilihat pada tabel 4.26

\begin{tabular}{|l|l|l|l|}
\hline No & Keterangan & $\begin{array}{l}\text { Banyak } \\
\text { Jawaban }\end{array}$ & Presentase (\%) \\
\hline 1 & Sangat Baik & 0 & 0 \\
\hline 2 & Cukup Baik & 0 & 0 \\
\hline 3 & Baik & 3 & 100 \\
\hline 4 & Kurang Baik & 0 & 0 \\
\hline 5 & Tidak Baik & 0 & 0 \\
\hline \multicolumn{2}{|l}{ Total Responden } & 3 & \\
\hline
\end{tabular}

Tabel 16. Hasil pengujian interaksi antara website dan pengguna

Berdasarkan hasil presentase pada tabel 4.26 maka dapat di simpulkan bahwa sebanyak 3 dari 3 orang responden atau $100 \%$ mengatakan interaksi antara website dan pengguna ( user ) dapat dipahami dengan baik
7. Pengujian informasi yang di sajikan website sudah memenuhi keinginan user dapat dilihat pada tabel 4.27

\begin{tabular}{|l|l|l|l|}
\hline No & Keterangan & $\begin{array}{l}\text { Banyak } \\
\text { Jawaban }\end{array}$ & $\begin{array}{l}\text { Presentase } \\
(\%)\end{array}$ \\
\hline 1 & $\begin{array}{l}\text { Sangat } \\
\text { Memenuhi }\end{array}$ & 0 & 0 \\
\hline 2 & Cukup Memenuhi & 0 & 0 \\
\hline 3 & Memenuhi & 0 & 0 \\
\hline 4 & $\begin{array}{l}\text { Kurang } \\
\text { Memenuhi }\end{array}$ & 2 & 66,67 \\
\hline 5 & Tidak Memenuhi & 1 & 33,33 \\
\hline \multicolumn{2}{|l|}{ Total Responden } & 3 & \\
\hline
\end{tabular}

Tabel 17. Hasil pengujian informasi yang di sajikan website

Berdasarkan hasil presentase pada tabel 4.27 maka dapat di simpulkan bahwa sebanyak 2 dari 3 orang responden atau $66,67 \%$ mengatakan informasi yang di sajikan website kurang memenuhi keinginan user dan sebanyak 1 dari 3 orang responden atau 33,33\% mengatakan informasi yang di sajikan website tidak memenuhi keinginan user

8. Pengujian Website ini sudah memenuhi syarat untuk bisa menjadi alternatif media informasi bagi member dapat dilihat pada table 4.28 dibawah ini.

\begin{tabular}{|l|l|l|l|}
\hline No & Keterangan & $\begin{array}{l}\text { Banyak } \\
\text { Jawaban }\end{array}$ & $\begin{array}{l}\text { Presentase } \\
(\%)\end{array}$ \\
\hline 1 & $\begin{array}{l}\text { Sangat } \\
\text { Memenuhi }\end{array}$ & 0 & 0 \\
\hline 2 & $\begin{array}{l}\text { Cukup } \\
\text { Memenuhi }\end{array}$ & 0 & 0 \\
\hline 3 & Memenuhi & 1 & 33,33 \\
\hline 4 & $\begin{array}{l}\text { Kurang } \\
\text { Memenuhi }\end{array}$ & 2 & 66,67 \\
\hline 5 & Tidak Memenuhi & 0 & 0 \\
\hline \multicolumn{2}{|l|}{ Total Responden } & 3 & \\
\hline
\end{tabular}

Tabel 18. Hasil pengujian website menjadi media informasi alternatif

Berdasarkan hasil presentase pada tabel 4.28 maka dapat di simpulkan bahwa sebanyak 1 dari 3 orang responden atau 33,33\% mengatakan informasi yang di sajikan website sudah memenuhi keinginan user dan sebanyak 2 dari 3 orang responden atau 66,67 \% mengatakan informasi yang di sajikan website kurang memenuhi keinginan user

9. Pengujian tampilan website ini sudah memenuhi syarat untuk dikatakan menarik dan mudah digunakan oleh setiap pengguna/pengunjung ? 


\begin{tabular}{|l|l|l|l|}
\hline No & Keterangan & $\begin{array}{l}\text { Banyak } \\
\text { Jawaban }\end{array}$ & $\begin{array}{l}\text { Presentase } \\
(\%)\end{array}$ \\
\hline 1 & $\begin{array}{l}\text { Sangat } \\
\text { Memenuhi }\end{array}$ & 0 & 0 \\
\hline 2 & $\begin{array}{l}\text { Cukup } \\
\text { Memenuhi }\end{array}$ & 0 & 0 \\
\hline 3 & Memenuhi & 3 & 100 \\
\hline 4 & $\begin{array}{l}\text { Kurang } \\
\text { Memenuhi }\end{array}$ & 0 & 0 \\
\hline 5 & Tidak Memenuhi & 0 & 0 \\
\hline Total Responden & 3 & \\
\hline
\end{tabular}

Tabel 19. Hasil pengujian tampilan website sudah menarik dan mudah digunakan

Berdasarkan hasil presentase pada tabel 4.29 maka dapat di simpulkan bahwa sebanyak 3 dari 3 orang responden atau $100 \%$ mengatakan interaksi antara website dan pengguna ( user ) dapat dipahami dengan baik

10. Pengujian website ini sudah layak untuk di online kan?

\begin{tabular}{|l|l|l|l|}
\hline No & Keterangan & $\begin{array}{l}\text { Banyak } \\
\text { Jawaban }\end{array}$ & $\begin{array}{l}\text { Presentase } \\
(\%)\end{array}$ \\
\hline 1 & $\begin{array}{l}\text { Sangat } \\
\text { Memenuhi }\end{array}$ & 0 & 0 \\
\hline 2 & $\begin{array}{l}\text { Cukup } \\
\text { Memenuhi }\end{array}$ & 0 & 0 \\
\hline 3 & Memenuhi & 3 & 100 \\
\hline 4 & $\begin{array}{l}\text { Kurang } \\
\text { Memenuhi }\end{array}$ & 0 & 0 \\
\hline 5 & Tidak Memenuhi & 0 & 0 \\
\hline Total Responden & 3 & \\
\hline
\end{tabular}

Tabel 20. Hasil pengujian website sudah layak untuk di online kan

Berdasarkan hasil presentase pada tabel 4.30 maka dapat di simpulkan bahwa sebanyak 3 dari 3 orang responden atau $100 \%$ mengatakan interaksi antara website dan pengguna ( user ) dapat dipahami dengan baik

\section{KESIMPULAN}

Dari hasil yang telah dilakukan penulis dapat menyimpulkan bahwa proses Aplikasi Penjualan Pakaian Couple pada Rain-D Shop Samarinda sebagai berikut: 1. Penyelesaian pekerjaan yang tadinya masih bersifat offline dapat dilakukan secara online dan salah satunya dengan mengg unakan Sistem Penjualan Pakaian Couple secara online.

2. Penginputan data pemesanan dilihat pada tampilan sistem menggunakan Aplikasi Penjualan Pakaian Couple pada Rain-D Shop Samarinda berbasis Web site dalam laporan ini, maka dapat memudahkan dalam proses pemesanan barang sesuai data yang berhasil diinputkan. 3. Dengan adanya hasil tampilan sistem, maka penyimpanan data sistem penjualan pakaian Couple berbasis $W E B$ menjadi lebih mudah.

\section{SARAN}

1.Diharapkan untuk pengembangan sistem ini selanjutnya bisa membahas mengenai keamanan sistem dimana keamanan merupakan hal paling berpengaruh untuk sebuah sistem toko online.
2. Aplikasi penjualan pakaian couple berbasis website inimasih dapat dikembangkan lagi dengan sistem pembayaran secara online seperti Paypal dan dengan kartu kredit.

3. Sistem Administrasi yang selalu dipelihara akan sangat mempengaruhi kelancaran aktivitas sistem penjualan pakaian Couple berbasis Web ini dalam menangani penjualan sehari-hari, maka hendaknya selalu memelihara sistem administrasi.

4. Kerjasama antara pihak yang satu dengan yang lain dalam organisasi dapat terjalin dengan baik.

\section{DAFTAR PUSTAKA}

Pressman, Roger, 2002, Rekayasa Perangkat Lunak Pendekatan Praktisi (Buku Satu), Yogyakarta: Andi Offset.

Buliali Joko Lianto. 2008, Penjualan Mobil Berbasis Web dan Manajemen Data Pembayaran di Showroom Mobil.

Dadan Sutisna, 2007,7 Langkah Muda Menjadi Web Master, M diakita, Jakarta

Dodit. 2008, Petunjuk Praktis Mendesain Web dan Berinternet Bagi Pemula, Data kan Lintas Buana.

Herman Suyanto Asep, 2007, Step By Step We Designer Theory And Proctices, Andi Yogyakarta.

HM Jogiyanto,2005, Analis dan Desain System Informasi, Andi Yogyakarta, yogyakarta.

Madcoms, 2008, Aplikasi program PHP dan MYSQL Untuk Membuat Web site Interaktif, Andi, Yogyakarta.

Musyawarah, 2004, Macromedia Studio MX (Integrasi Aplikasi Untuk Membangun Web site ), Andi Yogyakarta.

Nugroho, 2004, PHP \& My SQL dengan editor Dreamewaver $M X$, Andi, Yogyakarta.

Pangestu Danu Wira, 2009, Petunjuk Praktis Mendesain Web dan Berinternet bagi pemula.

Ramadhan Bayu. 2010, Membangun Web site Penjualan Produk yang Menarik.

Roger S.Pressman. 2002, Rekayasa Perangkat Lunak Pendekatan Praktis (buku 1). Andi, Yogyakarta.

Sastradipoera, Komaruddin, 2007, Sejarah pemikiran ekonomi suatu pengantar teori dan kebijaksanaan ekonomi, Kappa-Sigma, Bandung.

Suherman Hari. 2009, Memabangun Sistem Informasi Penjualan Berbasis Web Pada Toko Buku Aziz Samarinda.

Sutoro Djoko, 2007, Membuat Sistem Informasi Penjualan Berbasis Web, Yogyakarta : Gava Media.

Sutejo Budi dan Michael AN, 2000, Algoritma dan Teknik Pemrograman, Konsep Implementasi dan Aplikasi.

Purbo, Ono W dan Sembiring, Akhmad D, 2001. Buku Pintar Internet Apache Web Server. Jakarta : Elex Media Kamputindo 